\title{
Janet Goodwin Memorial Fund Iannched to support the future of dental nursing
}

When former Oral Health Foundation President Janet Goodwin died in October 2020 she left behind a great legacy. It is in recognition of this that the Oral Health Foundation have joined together with the British Association of Dental Nurses (BADN) to launch the Janet Goodwin Memorial Fund.

An influential figure within oral health, Janet spent much of her career championing the importance of education and the career development of dental nurses. It is for this reason that it seemed only fitting for a memorial fund to be set up in her name to further that cause.

The Janet Goodwin Memorial Fund will support dental nursing students and registered dental nurses with bursaries for the development of their careers. For dental nursing students, this might take the form

of financial help with their education, while qualified dental nurses can apply for support with postgraduate studies.

The Oral Health Foundation and BADN hopes the new series of grants can help provide much needed financial support for individuals pursuing a career in dental nursing.

Dr Nigel Carter OBE, Chief Executive of the Oral Health Foundation, believes the fund goes straight to the heart of Janet's work.

Dr Carter says: 'I would like to think Janet would be really proud by a project like this. During her distinguished career, Janet battled hard for her profession and made fantastic strides in boosting the visibility of dental nursing amongst the profession and the public.

'Janet was a terrific ambassador for her fellow dental nurses and what better way to honour that than through a fund which will help dental nurses further their careers. By providing support for our future dental nurses, as well as current ones, this fund will help secure a stronger and brighter future for dentistry as a whole.'

Janet was used to breaking down barriers during her career and was passionate about improving the oral health of people up and down the country.

In 2015, Janet became the first dental nurse to be elected President of the Oral Health Foundation in the charity's nearly 50 -year history. She also was the first dental nurse admitted to the General Dental Council. Always looking for new challenges, Janet was also Chair of the National Examining Board for Dental Nurses - only the second dental nurse to hold that position - and later employed by the NEBDN as Qualifications Manager.

Janet was a long-time active member, and Fellow, of the British Association of Dental Nurses and was also a recipient of their 'Outstanding Contribution to Dental
Nursing Award'.

Jacqui Elsden, President of the British Association of Dental Nurses, said: 'It is without doubt that Janet will be truly missed across the dental community. She was a wonderful advocate for our dental nursing profession, particularly for dental nurse education and oral health care. I feel immensely proud to be part of the collaboration leading to the founding of the Fund in her memory. It will be a unique opportunity for dental nurses to begin or further their career in dental nursing and inspire a new generation'

To find out more about the Janet Goodwin Memorial Fund and to make a donation, visit www.dentalhealth.org/ janetgoodwin.

\section{BSDHT SUPPORTS PATIENT GUM HEALTH WITH FLOSSUARY}



The British Society of Dental Hygiene and Therapy (BSDHT) is delighted to be supporting Flossuary - an initiative running this February designed to help patients improve their gum health.

The aim is to challenge patients to clean interdentally once a day for 28 consecutive days, enabling them to see the difference this can make to their gum health. There is also an online resource - https:// flossuary.com/ - accessible to all that provides advice on easy-to-use, good value products recommended by professionals. It includes instructional videos, information on the benefits of effective interdental cleaning, and a Flossuary starter pack free for any UK resident.

Diane Rochford, BSDHT President, said: 'The practice I work at will be participating, not only as a way to motivate patients during this current lockdown, but also as a team we will take up the challenge!'

Visit the website or follow BSDHT on social media for more information and ideas on how to engage with your patients this Flossuary. 